\title{
A homeo domain protein reveals the metameric nature of the developing chick hindbrain
}

\author{
Olof H. Sundin and Gregor Eichele \\ Department of Cellular and Molecular Physiology, Harvard Medical School, Boston, Massachusetts 02115 USA
}

\begin{abstract}
The segmented embryonic hindbrain of vertebrates develops by sequential constriction of the neural tube into eight metameric units known as rhombomeres. The cellular and molecular basis of this segmentation process is largely unknown. Using an antibody, we analyzed the expression pattern of the chick homeo domaincontaining protein Ghox-lab in the developing chick hindbrain. At the neural plate stage, prior to the appearance of rhombomeres, Ghox-lab is expressed within a single domain that extends anteriorly up to the site where rhombomere 4 will later form. After rhombomere 4 has appeared and as hindbrain segmentation progresses, the level of Ghox-lab protein increases significantly within the fourth rhombomere. This intensification, accompanied by the elimination of Ghox-lab protein in rhombomeres 5 and 6 , eventually results in the formation of a distinct island of expression in rhombomere 4 . All cells in the newly formed rhombomere 4 express Ghox-lab, except for the cells of the floor plate. In addition, neural crest cells migrating from the fourth rhombomere are also Ghox-lab-positive. These data raise the possibility that Ghox-lab protein might be one of the factors involved in the specification of the metameric pattern of the vertebrate hindbrain.
\end{abstract}

[Key Words: Homeo box; pattern formation; rhombomere; segmentation; hindbrain; chick]

Received March 16, 1990; revised version accepted June 5, 1990.

It has long been proposed that vertebrates are segmented in the manner of annelids and arthropods. The earliest observations of segmentation in the vertebrate central nervous system come from the classical studies by von Baer (1828), who described periodic bulges of the neural tube in the early chick embryo. These bulges were later designated as neuromeres (Orr 1887). The metameric nature of the neural tube is especially pronounced in the rhombencephalon (hindbrain), where up to eight rhombomeres transiently form and then disappear during embryogenesis (Vaage 1969). Although the lack of overt segmentation in the adult hindbrain calls into question the significance of these transient embryonic segments, their presence throughout the vertebrates indicates a crucial role in development. One imprint that this embryonic segmentation leaves on the adult hindbrain is a highly conserved morphological relationship in which individual rhombomeres give rise to particular cranial nerves (Orr 1887; Vaage 1969; Lumsden and Keynes 1989).

There has been renewed interest in the metameric organization of the vertebrate hindbrain (Keynes and Lumsden 1990), particularly in the context of insect development. In insects, the identity of segments along the anteroposterior axis is determined largely by the expression pattern of a set of homeotic selector genes clustered in the Antennapedia and Bithorax complexes (ANT-C and BX-C; see Lewis 1978; Duncan 1987; Mahaffey and
Kaufman 1989|. These genes encode transcription factors (Struhl et al. 1989; Winslow et al. 1989) that contain a homeo domain, an evolutionarily conserved DNA-binding motif (McGinnis et al. 1984; Gehring 1987; Qian et al. 1989|. Genes of the ANT-C and BX-C have cognates in mammalian genomes that are also arranged in clusters $($ Hox $-1,-2,-3,-4$; for review, see Boncinelli et al. 1989). Interestingly, the organization of the Hox clusters resembles that of Drosophila ANT-C and BX-C (Duboule and Dollé 1989; Graham et al. 1989; for review, see Akam 1989).

Although the expression patterns of the Drosophila ANT-C and BX-C genes are restricted to parasegmental units (Martinez-Arias and Lawrence 1985; for review, see Akam et al. 1988), most vertebrate cognates are expressed in broad and overlapping domains of the CNS, usually devoid of any recognizable metameric pattern (e.g., Holland and Hogan 1988). However, examination of mouse embryos with well-developed rhombomeres reveals that when the anterior limit of expression of a Hox gene falls within the hindbrain, this limit consistently coincides with a rhombomere border (see Wilkinson et al. 1989b). Of particular interest to this report is the observation that in the hindbrain Hox-2.9 mRNA is localized specifically in rhombomere 4 (Murphy et al. 1989; Wilkinson et al. 1989b).

In an earlier study (Sundin et al. 1990), we characterized Ghox-lab, a chicken Hox gene related to labial, a 
Drosophila homeotic selector gene (Diederich et al. 1989/. Using in situ hybridization, we found that in primitive streak and head process-stage chick embryos, Ghox-lab expression defines two regions: Ectoderm, mesoderm, and endoderm in the prospective trunk express Ghox-lab, whereas tissues fated to become head lack Ghox-lab transcripts. The border between Ghoxlab-positive and Ghox-lab-negative cells lies in a region fated to form hindbrain (Spratt 1952). In the work reported here, we use an antiserum directed against the protein encoded by Ghox-lab to describe how a single domain of expression evolves into an intricate pattern that reflects the metameric nature of the hindbrain and its associated neural crest.

\section{Results}

In situ hybridization and antiserum detect high levels of Ghox-lab expression in rhombomere 4

In situ hybridization of serial sagittal sections through Hamburger-Hamilton stage 15 embryos revealed the presence of Ghox-lab mRNA along the entire length of the spinal cord (Sundin et al. 1990; and unpubl.). Sections passing through the hind- and midbrain displayed a well-demarcated region of neuroepithelium that was Ghox-lab-positive (Fig. 1A). The silver grain distribution had a clear anterior and posterior boundary, suggesting that the Ghox-lab-positive tissue corresponds to one of the rhombomeres. In an effort to determine which rhombomere was expressing Ghox-lab, sections parallel to that illustrated in Figure $1 \mathrm{~A}$ were reconstructed serially (not shown). It was straightforward to identify rhombomeres 5 and 6 as they are proximal to the otic vesicle, a distinct landmark in the vertebrate hindbrain. Because the Ghox-lab-positive neuroectoderm is situated immediately anterior to rhombomere 5 , it must be the neuroectoderm of rhombomere 4.

These in situ hybridization studies have two limitations: First, it remains unknown whether Ghox-lab transcripts are translated; second, assuming that this gene is involved in the determination of cell fate in the hindbrain, it becomes critical to find out whether or not all cells in rhombomere 4 express Ghox-lab. Such cellular resolution requires an antibody. Therefore, we prepared a rabbit antiserum to an Escherichia coli trpE fusion protein that contained protein encoded by the upstream, nonhomeo box exon of Ghox-lab (for sequence data and gene structure, see Sundin et al. 1990). The serum was affinity-purified with a fusion protein consisting of LacZ and the first 94 amino acids of Ghox-lab protein. It should be noted that this portion of the protein shows no homology to mouse Hox-1.6 or Hox-2.9, with the exception of a short sequence extending from the amino terminus (Sundin et al. 1990; Frohman et al. 1990). In addition, it was observed by immunohistochemistry that the antibody yields no detectable signal in the nuclei of mouse embryo sections and gives only a weak signal with quail, a bird closely related to the chicken (data not shown). The fact that the antiserum exhibits such a high degree of species specificity argues that it should not cross-react to any significant extent with proteins encoded by other homeo box genes of the chick.

The regions of the embryo in which nuclear signal was detected were those that also contain Ghox-lab mRNA (for in situ hybridization data, see Sundin et al. 1990). Specifically, antibody signal was present in spinal cord (Figs. 2B-J), in somites (e.g., Fig. 2B), in posterior flank mesoderm (not shown), in gut-associated splanchnic mesoderm (not shown), and in foregut endoderm (Fig. 1A; e.g., Fig. 2E). In contrast, signal was completely absent in all neural and mesenchymal tissue anterior to the hindbrain. Examination of a frontal section of a stage 17 chick embryo (Fig. 1C) illustrates the distribution pattern in the hindbrain. The highest level of signal is found in the neuroectoderm of rhombomere 4. There is no signal in the anterior rhombomeres $1-3$ or in rhombomeres 5 and 6; however, Ghox-lab is expressed at modest levels in rhombomeres 7 and 8 (Fig. $1 \mathrm{Cl}$, as well as along the entire length of the spinal cord (not shown). We conclude that in situ hybridization (Fig. 1A) and immunohistochemistry (Fig. 1C) consistently detect expression of Ghox-lab in rhombomere 4.

\section{All cells in the neuroectoderm of rhombomere 4 express Ghox-lab protein but not cells of the floor plate}

To determine whether all cells in the domain of rhombomere 4 express Ghox-lab, we examined sagittal and transverse sections through rhombomere 4 . Because Ghox-lab protein is localized tightly to the nucleus (Fig. 1B), the precipitated immunoperoxidase reaction product effectively quenched the fluorescence emitted by the DNA-bound Hoechst dye. This quenching allows one to readily recognize Ghox-lab-negative nuclei, as these will stand out against the background. Figure 1, C and $D$, shows that in the main body of the fourth rhombomere, all cells express Ghox-lab. An apparent exception concerns the few intensely fluorescent features near the ventricular surface (Fig. 1D). Inspection of these features at high magnification revealed that they are mitotic chromosomes (not shown). It has been observed previously that caudal, a Drosophila homeo domaincontaining protein, is found normally in the nucleus but is not bound to the chromosomes during mitosis (Macdonald and Struhl 1986).

The ventral midline of the neural tube constitutes a special structure known as the floor plate. The floor plate has an embryonic origin separate from lateral neuroectoderm (Schoenwolf et al. 1989) and appears to perform important functions such as axon guidance within the developing central nervous system (Jessell et al. 1989). Floor plate cells in the spinal cord contain Ghox-lab protein (not shown), but the floor plate of rhombomere 4 shows no immunoreactivity (see Fig. 1D). At stage $11^{-}$, shortly after the fourth rhombomere has formed (for a summary of hindbrain morphogenesis, see Fig. 4), an optical section passing through the floor plate 

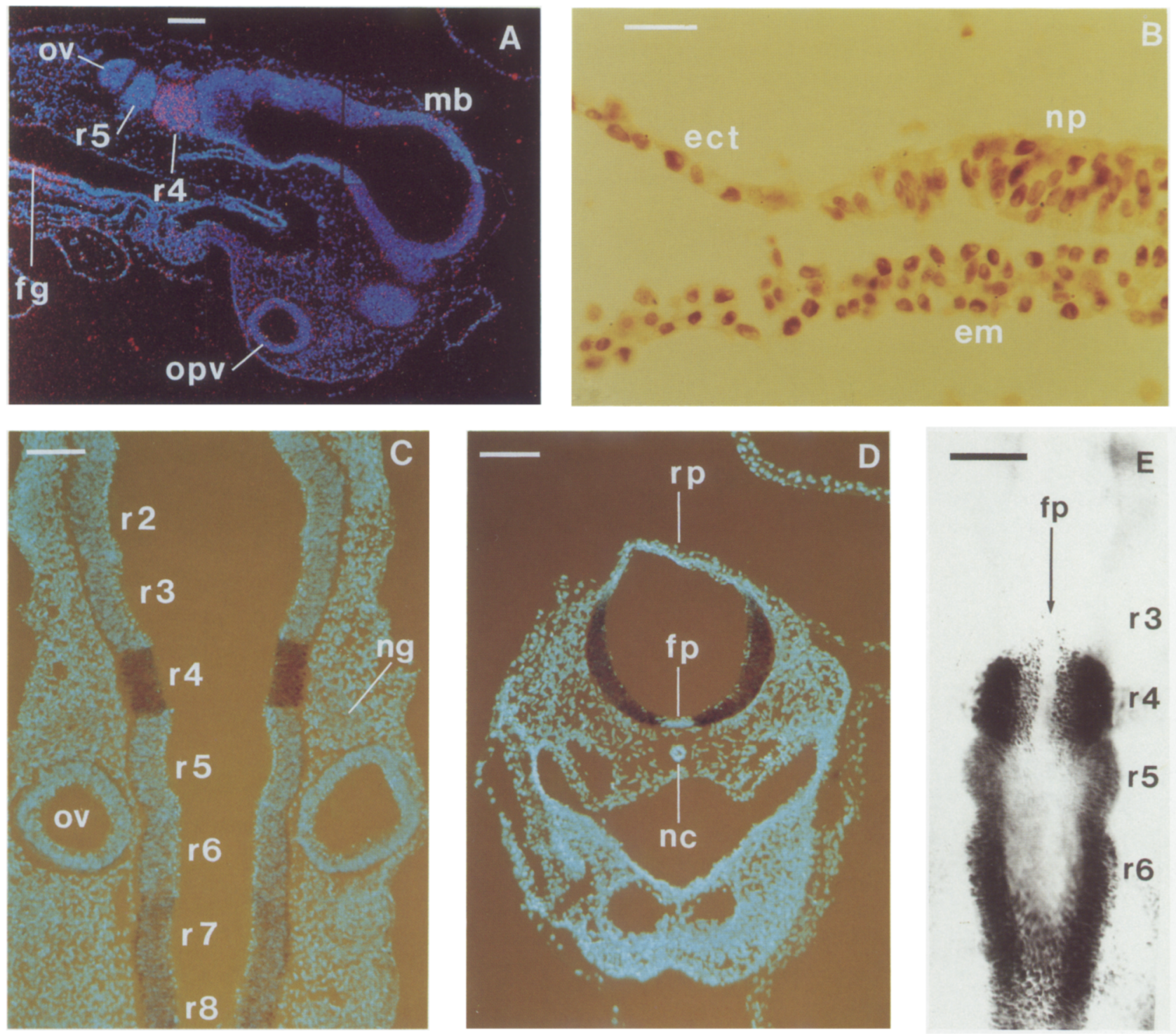

Figure 1. $(A)$ Rhombomere 4-specific expression of Ghox-lab revealed by in situ hybridization. This parasagittal section of a stage 15 chick embryo passes through the medial face of the otic vesicle, the lateral walls of rhombomeres $3-5$, and the lumen of the anterior hindbrain and midbrain. The embryo is visualized by the fluorescence of Hoechst-stained nuclei (blue), whereas the ${ }^{35} \mathrm{~S}$-labeled hybridization signal appears as silver grains (red). Orientation: Anterior is to right and dorsal is up. Bar, $100 \mu \mathrm{m}$. (B) Distribution of Ghox-lab protein at cellular levels. A stage $7^{+}$embryo was immunoperoxidase-stained in whole mount with Ghox-lab antibody. It was then embedded in paraffin and sectioned transversely at the level of the first somite. The reddish-brown diaminobenzidine reaction product is viewed by bright-field illumination. Note the nuclear localization of the signal. Orientation: Dorsal up; lateral to left. Bar, $20 \mu \mathrm{m}$. (C) Expression of Ghox-lab in rhombomere 4. A $20-\mu \mathrm{m}$ frozen frontal section through the hindbrain region of a stage 17 embryo was stained with Ghox-lab antibody. Bright-field illumination reveals the peroxidase reaction product (brown) in labeled nuclei, and Hoechst fluorescence (blue) reveals the unlabeled nuclei. This specimen exhibits high levels of Ghox-lab protein in rhombomere 4 and significantly lower levels in rhombomeres 7 and 8 . Mesenchyme, otic vesicle, the seventh/eighth cranial nerve and ganglion, and rhombomeres 2, 3, 5, and 6 are all Ghox-lab-negative. Orientation: Anterior up. Bar, $100 \mu \mathrm{m}$. $(D)$ Transverse section of a stage 15 embryo passing through rhombomere 4 (photographed in the same manner as in Fig. 1C). All cells in rhombomere 4 express Ghox-lab, except for cells in the floor plate and roof plate. Examination at higher magnification (not shown) reveals that the Hoechst fluorescent features at the inner surface of the tube are mitotic chromosomes, and the cytoplasm of these mitotic cells stains with the Ghox-lab antibody. Orientation: Dorsal up. Bar, $100 \mu \mathrm{m}$. (E) A stage 11 embryo whole-mount immunoperoxidase stained for Ghoxlab. Optical section through the floor plate of the hindbrain, viewed from above in bright-field illumination. Notice how the Ghoxlab-positive neuroepithelial cells in rhombomere 4 closely abut the negative floor plate. Orientation: Anterior up. Bar, $100 \mu m$. Abbreviations: (ect) ectoderm; (em) endo-mesoderm; $(\mathrm{fg})$ foregut endoderm: (fp) floor plate; $(\mathrm{mb})$ midbrain; $(\mathrm{ng})$ seventh/eighth nerve root and ganglion; (np) neural plate; $(\mathrm{nc})$ notochord; (opr) optic vesicle; (ov) otic vesicle; (r2-r8) rhombomeres 2-8; (rp) roof plate. 
of a whole mount (Fig. 1E) reveals that Ghox-lab-positive neurectodermal cells in rhombomere 4 are crowded up to the edge of the entirely negative floor plate. The expression pattern of Ghox-lab in the floor plate of earlier embryos is schematized in Figure 4. Another region in the neural tube of the stage 15 embryo devoid of
Ghox-lab protein is the thin roof plate (Fig. 1D). Earlier, in stage 12 embryos, when the roof plate is thicker, its cells express Ghox-lab protein (not shown). The loss of expression in the roof plate occurs long after the appearance of rhombomere 4 and at a time when the levels of Ghox-lab mRNA are already in decline.

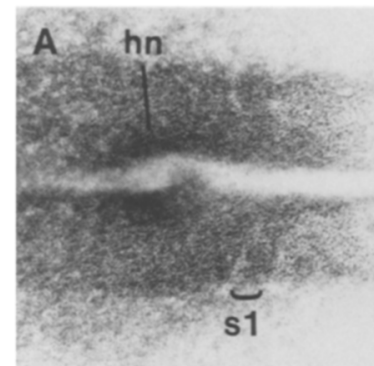

B

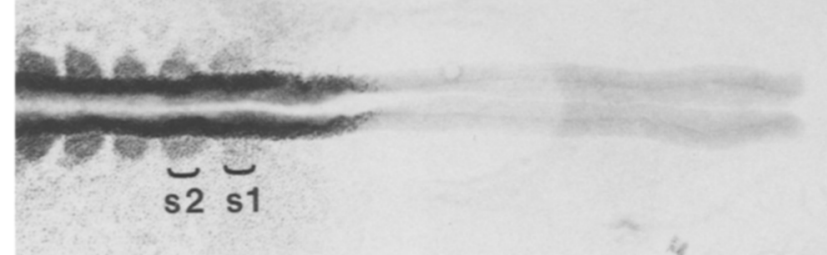

C

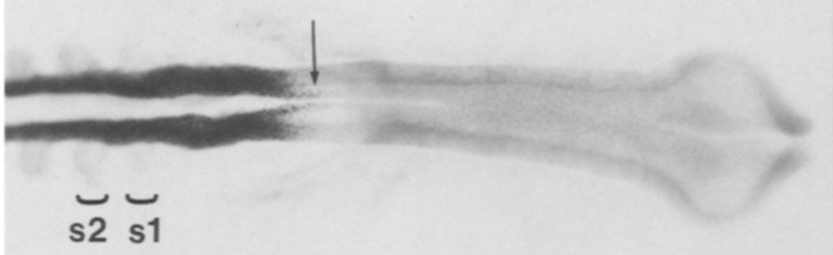

9

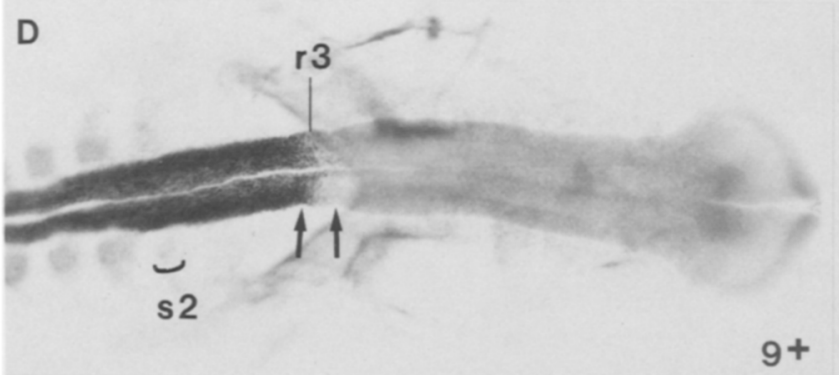

7
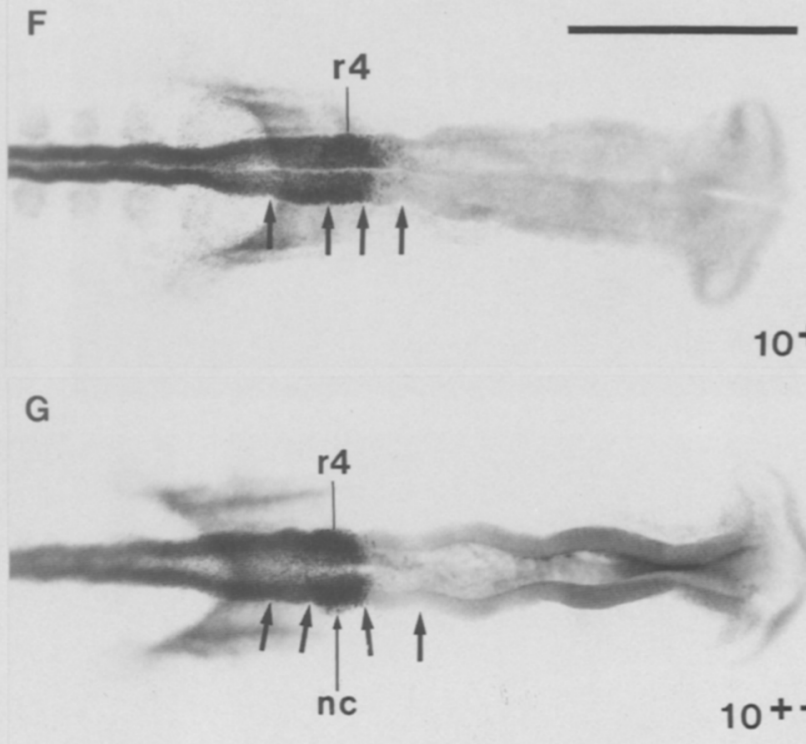

H

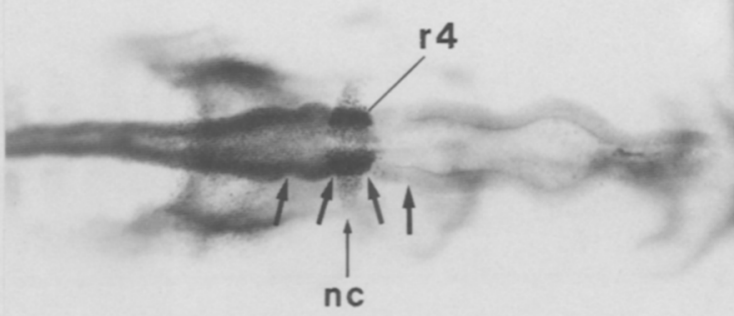

$11^{-}$

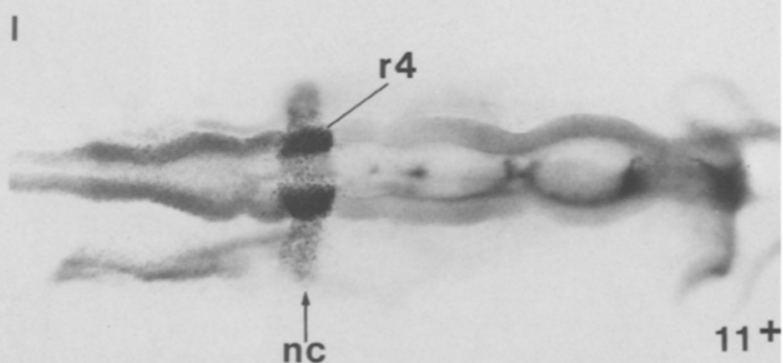

E

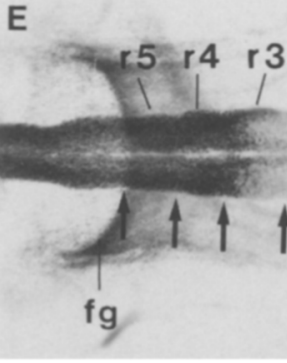

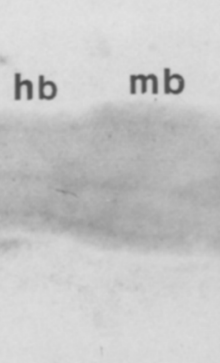

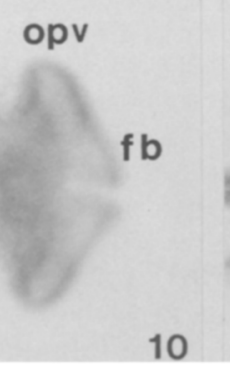

$$
J
$$

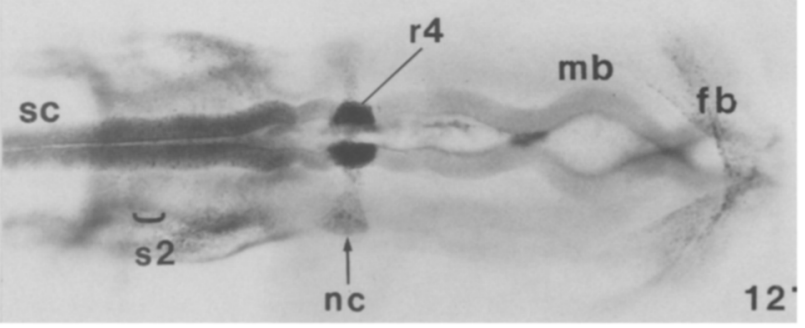

Figure 2. (See facing page for legend.) 
Development of the expression pattern in rhombomere 4

In situ hybridization to transcripts of Ghox-lab (see Fig. 5 in Sundin et al. 1990) and localization of its protein by immunohistochemistry (Fig. 2A) show that at the neural plate stages, it is expressed throughout the presumptive trunk up into the presumptive hindbrain. In contrast, presumptive midbrain and forebrain do not express Ghox-lab. At stage 15, when all rhombomeres have formed and neurons begin to differentiate, a similar simple pattern is still recognizable. A continuous stretch of Ghox-lab expression is seen in rhombomeres 7 and 8 (Fig. 1C) and extends posteriorly along the entire length of the spinal cord. Anterior to this uninterrupted stretch of expression is the insular region of expression in rhombomere 4 (Fig. 1C). Does this "island" of expression arise by de novo activation of the Ghox-lab gene in a previously negative region of anterior neuroectoderm? Alternatively, does it arise in a domain of the hindbrain that already expresses the gene?

To distinguish between these two possibilities, we examined a developmental series of embryos stained with Ghox-lab antiserum. A representative selection of these embryo whole mounts is reproduced at identical magnification in Figure 2. The embryos range from stages 7 to 12 and cover the period of hindbrain segmentation (for a time frame of rhombomere formation, see Fig. 4). Figure $2 \mathrm{~A}$ shows the flat neural plate of a stage 7 embryo. Granular, that is, nuclear, signal of the homeo domain protein is seen in the neural plate, as well as in mesodermal tissues that are below the neural plate (see also Fig. 1B). The anterior boundary of expression does not coincide with any distinct morphological landmarks but is situated substantially anterior to the first somite. It should be noted that the overall level of Ghox-lab expression at its anterior boundary is lower than in tissue nearer the somite (Fig. 2A). This is due to the interspersion of Ghox-lab-negative and Ghox-lab-positive cells and not to a uniform decrease in the level of expression. By stages $8^{+}$and 9 (Fig. 2B,C) a "filling-in" process has taken place, and essentially all cells near this anterior boundary express Ghox-lab. Furthermore, the boundary appears to have a fixed position along the anteroposterior axis relative to the somites and the head end /cf. Fig. 2A-D). Another feature of this boundary, one that persists through later stages of tube closure and rhombomere formation, is the slight tendency of positive cells to sweep anteriorly along the midline and the lateral edges of the plate (see Fig. 2A and arrow in Fig. 2C).

The stage $9^{+}$embryo depicted in Figure 2D is especially important as it shows two closely spaced constrictions (arrows) that have just become visible in the hindbrain. These constrictions mark the anterior and posterior boundaries of rhombomere 3 according to the scheme of Vaage (1969). The more posterior of these constrictions also defines the anterior limit of rhombomere 4. Close examination reveals that the pattern of Ghox-lab expression does not follow precisely the newly formed rhombomeric constrictions. At this early stage, many positive cells are found scattered randomly within the boundaries of rhombomere 3 (Fig. 2D-F). At stage 10 (Fig. 2E), the posterior limit of rhombomere 4 is established, but at this point, there is no selective increase in Ghox-lab expression within the newly formed rhombomere. It is not until stages $10^{+}$and $10^{2+}(11$ and 11.5 somites; Fig. 2F,G) that one observes an increase in Ghox-lab expression within rhombomere 4. However, in more posterior regions of the hindbrain and in the spinal cord, expression remains uniform. Less than an hour later, by stage $11^{-}$(Fig. $\left.2 \mathrm{H}\right)$, the intensity of signal in rhombomere 4 is greatly increased. By stage $11^{+}$, the level of Ghox-lab antigen has decreased significantly in the posterior rhombomeres and spinal cord. By stage $12^{-}$ (Fig. 2J), rhombomere 5 is devoid of Ghox-lab-positive nuclei, and by stage 17 (Fig. 1C), signal has also been lost from rhombomere 6.

In summary, the developmental series depicted in

Figure 2. Developmental profile of Ghox-lab protein distribution in the chick hindbrain (stages 7-12). Embryos stained in whole mount with Ghox-lab antibody. Dorsal views of the anterior portion of the embryo, including anterior spinal cord, hind-, mid- and forebrain. All frames are at identical magnification, with the bar in $4 \mathrm{~F}$ representing $500 \mu \mathrm{m}$. Somites are useful reference points along the anteroposterior axis, and their locations $(s 1, s 2)$ are indicated by horizontal brackets. They are also useful for marking time, as one set is added roughly each hour (Hamburger and Hamilton 1951). (A) A stage 7 embryo. Neural plate stage with one somite. (B) A stage $8^{+}$embryo. Neural-fold stage, with five somites. Somites express Ghox-lab. $(C)$ A stage 9 embryo, with seven somites. The neural tube is largely closed. Arrow indicates stray cells anterior to the main expression domain. $(D)$ A stage $9^{+}$embryo with eight somites. Two constrictions appear (arrows), defining rhombomere 3. (E) A stage 10 embryo with 10 somites. The constrictions defining rhombomere 4 and 5 appear (arrows). Note stray Ghox-lab-positive cells in rhombomere 3 . (F) A stage $10^{+}$embryo with 11 somites. A slight increase in Ghox-lab expression becomes visible within rhombomere 4. $(G)$ A stage $10^{2+}$ embryo, with 11 somites. Further intensification of Ghox-lab signal is visible in rhombomere 4. The slight lateral spreading seen best in the right half of rhombomere 4 (thin arrow) is the neural crest emerging from the dorsal midline of the neuroepithelium. $(H)$ A stage $11^{-}$embryo, with 12 somites. The Ghox-lab-positive neural crest (arrow) migrates laterally, and intensification of expression with rhombomere 4 reaches a maximum. (I) A stage $11^{+}$embryo, with 14 somites. Rhombomere 4 neural crest (arrow) migrates farther outward. There is now significantly less signal in posterior rhombomeres. (/) A stage 12- embryo, with 15 somites. Ghox-lab-positive neural crest (arrow) coalesces into ganglia. Rhombomere 5 has lost signal completely. The identity of Ghox-lab-positive cells in the body wall lateral to rhombomeres 6-8 is not yet clear, but we suspect that these are probably also neural crest cells. The underlying arch-like immunopositive feature seen most clearly in $E$ is foregut endoderm. Note: Background and stain-trapping artifacts visible in the anterior regions of the head (e.g., $G, I$ ) do not exhibit the characteristic nuclear localization of true Ghox-lab signal. Orientation: Anterior to right. Abbreviations: (fb) forebrain; ( $\mathrm{fg}$ ) foregut endoderm; (hb) hindbrain; (hn) Hensen's node; (mb) midbrain; (S1 or S2) somite position; (nc) neural crest; (r3-r5) rhombomeres $3-5$. Selected rhombomere constrictions are marked by heavy arrows. 
Figure 2 and schematized in Figure 4 suggests that right from the beginning of hindbrain formation and before the appearance of morphologically detectable constrictions, Ghox-lab is expressed all the way to the presumptive boundary of rhombomere 4 . After the morphological delineations of rhombomere 4 appear, rhombomere 4specific expression intensifies. Subsequently, Ghox-lab protein levels decline in rhombomeres 5 and 6 ; hence the island of Ghox-lab expression in rhombomere 4 is sculpted from an initially uniform expression pattern and is not the result of induction of Ghox-lab in a previously nonexpressing region of the neuroectoderm.

\section{Neural crest cells derived from rhombomere 4 express Ghox-1ab}

A novel feature revealed by the Ghox-lab antiserum not seen by in situ hybridization is that neural crest cells emerging from rhombomere 4 also express the gene, although at a level lower than in the rhombomere itself. The stage $12^{-}$whole-mount embryo shown in Figure 2J revealed Ghox-lab signal in two dumbbell-like structures extending distally from rhombomere 4 (arrow). An embryo stained for the HNK-1 antigen (Fig. 3, left), a marker found on migratory neural crest cells (Vincent and Thiery 1984), showed that these structures conform to the shape and position of genuine neural crest. The origin of these cells can be traced in the embryo series depicted in Figure 2G-J. When Ghox-lab expression begins to intensify in rhombomere 4 at stage $10^{2+}$, one can observe a rounded front of cells pointing laterally away from the neural tube (see thin arrow in Fig. 2G). By stage $11^{-}$, cells in the center of this mass move distally, lending the migrating crest a triangular appearance (Fig. $2 \mathrm{H})$. By stage $11^{+}$, the population has spread out into a

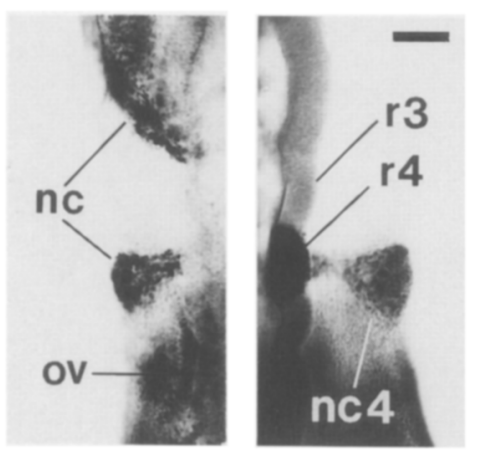

Figure 3. Neural crest cells and Ghox-lab-positive cells of the hindbrain. Stage 12- embryos stained in whole mount with either Ghox-lab or leu 7 antibody (HNK-1) and photographed in bright field with high-contrast film. (Left) HNK-1 staining reveals the distinct shape of the neural crest cell population derived from the fourth rhombomere and crest in anterior regions of the hindbrain. (Right) Another embryo stained with Ghoxlab antibody reveals signal in rhombomere 4 crest and possibly more posterior crest cells (dark region under nc4 label). Bar, 100 $\mu \mathrm{m}$. Abbreviations: (nc) neural crest; (nc4) neural crest derived from rhombomere 4 ; (ov) otic vesicle; $(\mathrm{r} 3, \mathrm{r} 4)$ rhombomeres 3 and 4. tongue-like configuration (Fig. 2I). At stage 12-, the cells begin to coalesce distally, and the stalk becomes thinner (Figs. 2J and 3, right). These condensed cells are fated to form the glial anlage of the seventh and eighth cranial nerves and their associated sensory ganglia (De Lièvre and Le Douarin 1982; D'Amico-Martel and Noden 1983). The eventual function of these ganglia is to relay sensory information from the face and ear to the brain. Expression of the protein in the crest cells begins to decline by stage 12 and has completely vanished by stage 15 (data not shown). Hence, within the time frame of gangliogenesis, the period of Ghox-lab expression is relatively brief, as ganglia continue to develop well past stage 24 .

\section{Discussion}

\section{Rhombomere unit}

We have studied the distribution of Ghox-lab protein at the cellular level and can now draw a detailed picture of its pattern of expression in relation to the metameric organization of the hindbrain. It is an intricate relationship that changes during development and culminates in a pattern where Ghox-lab protein is largely restricted to rhombomere 4 (Fig. 4). In the mouse, such a rhombomere-restricted pattern is exhibited by Hox-2.9 (Murphy et al. 1989; Wilkinson et al. 1989b; Frohman et al. 1990) but not by any of the other Hox genes studied to date. The conservation of this pattern between birds and mammals indicates that Ghox-lab and Hox-2.9 each play an important role in rhombomere 4 development. The similarity of their homeo boxes also suggests that they are functionally homologous. A central question left unanswered by the recent in situ hybridization studies with Hox-2.9 (Murphy et al. 1989; Wilkinson et al. 1989b) and the related Ghox-lab gene (Fig. 1A) is whether all or only a fraction of cells within the fourth rhombomere express this homeo box gene. In the case of Ghox-lab, we find that there is a domain in rhombomere 4 within which all cells contain Ghox-lab protein (Fig. $1 \mathrm{C}, \mathrm{D})$. Because of this all-inclusive expression pattern, it is possible that lab is involved in determining the segmental identity of this Ghox-rhombomere and could therefore be the vertebrate equivalent of a Drosophila homeotic selector gene (for review, see Akam et al. 1988; Peifer et al. 1987). Ghox-lab has the opportunity of time and place to influence neuronal fates, because it is expressed at high levels within the rhombomere prior to and during the birth of these motoneurons (Kuratani et al. 1988; Covell and Noden 1989; Lumsden and Keynes 1989|. If Ghox-lab behaves like a selector gene, it could also program the neural crest of rhombomere 4 to form the very distinctive glial anlage of the facial and acoustic ganglia (Vaage 1969; Le Lièvre and Le Douarin 1982; D'Amico-Martel and Noden 1983). Experimental evidence demonstrates early imprinting in the case of the premigratory cranial neural crest (Noden 1983). Presumptive mandibular arch crest cells grafted into a region near the second arch were found to migrate into 
this arch and generate an additional jaw, complete with skeleton and muscles.

Another novel feature revealed by the antibody is that the cells of the floor plate of rhombomere 4 do not express Ghox-lab. The floor plate has an embryonic origin distinct from that of the lateral neuroectoderm (Schoenwolf et al. 1989) and functions in axonal guidance (Jessell et al. 1989). As can be seen in Figure 4, floor plate cells adjacent to presumptive rhombomere 4 do not express Ghox-lab, even at early stages. However, more posterior floor plate cells contain Ghox-lab protein, but the pattern shows no segmental features. This suggests that the floor plate does not constitute part of the segmental unit, an idea supported by its lack of any morphological segmentation (Lumsden and Keynes 1989). The rhombomere thus appears as a curious segmental unit that consists of two separated halves, quite different from the contiguous parasegments of the Drosophila blastoderm (Martinez-Arias and Lawrence 1985; Lawrence 1988).

\section{Developing pattern of Ghox-lab expression}

In the chick and other vertebrates, rhombomeres are formed in a sequential manner, beginning with rhombomere 3 (Vaage 1969). The successive appearance of rhombomeres and the chief features of Ghox-lab expression are schematized in Figure 4. In essence, the relatively simple early phase of Ghox-lab expression (stages 7-10, Fig. 4) evolves into the rhombomere-restricted pattern seen in later embryos (stages $10^{+}$to 17 , Fig. 4). Early, at the neural plate stage (stage 7, Figs. 2A and 4), Ghox-lab protein is expressed throughout the neuroectoderm up to a region $\sim 250 \mu \mathrm{m}$ anterior to the first somite. The lack of appropriate fate maps makes it difficult to determine precisely the future position of cells in this boundary region. However, a simple side-by-side comparison of Figure 2A-D reveals that at the neural plate stage the anterior extent of Ghox-lab protein expression falls within the region in which the anterior border of rhombomere 4 will later form. Such a direct comparison seems warranted for two reasons: (1) The region is quite close to a visible marker, the first somite; and (2) during the period considered, there seems to be no significant extension of the neuroectoderm along the anteroposterior axis between the first somite and the front end of the embryo. Hence, it appears that within the limits of our observations the anterior border of expression of Ghox-lab represents a molecular prepattern visible well before the morphological appearance of the anterior border of the fourth rhombomere.

Further development of Ghox-lab expression in the hindbrain yields a rhombomere-specific pattern through a "sculpting" of the simple "block" of early expression. Initially, the anterior limit of Ghox-lab-expressing cells comprises a mixture of Ghox-lab-positive and Ghox-labnegative cells (Figs. 2A and 4, stage 7). As the neural plate folds and closes, this boundary becomes more distinct. However, even when the constriction separating rhombomeres 3 and 4 first appears (stage $9^{+}$; see Figs. 2D and 4), there is some variability in the anterior boundary of Ghox-lab expression between embryos. Furthermore, we consistently observe Ghox-lab-positive stray cells in rhombomere 3 . Somehow, these will eventually vanish. One possible explanation is that they eventually migrate into rhombomere 4. An alternate explanation is that these stray cells remain within rhombomere 3 but that they cease to express Ghox-lab once they assume a rhombomere 3 identity. A very recent study of single cell lineages in the chick hindbrain (Fraser et al. 1990)
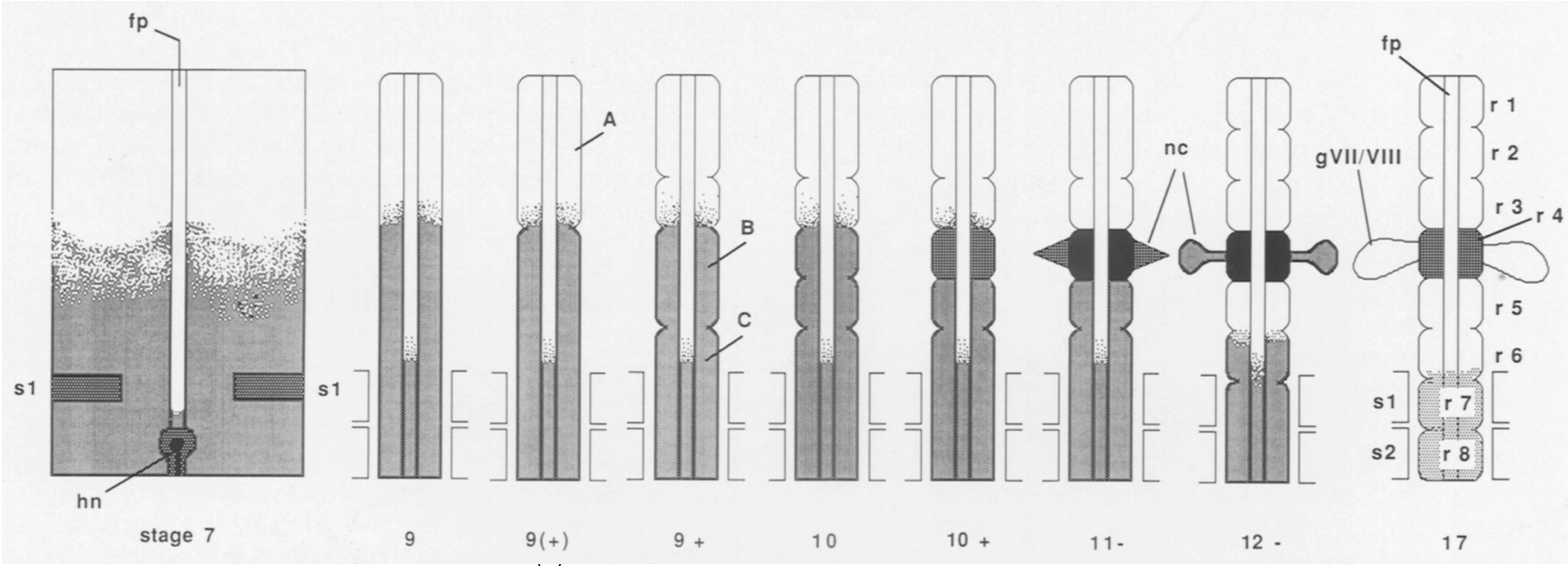

Figure 4. Summary: Expression of Ghox-lab during hindbrain development. The scheme shows a sequence of icons that illustrate the morphological development of the embryonic chick hindbrain. Included in these icons depicting the ventral aspect of the neural plate and tube are the floor plate, the segmental units of the neuroepithelium (initially proneuromeres A-C and, subsequently, rhombomeres 1-8), and the neural crest cell population originating in rhombomere 4 . The series begins with the one somite neural plate embryo (stage 7) and ends at stage 17, when all rhombomeres are formed and neurons differentiate within the hindbrain. Superimposed on these icons is the pattern and level of expression of Ghox-lab protein, as revealed by antibody histochemistry of wholemount embryos and sections. Density of shading reflects the level of expression of Ghox-lab. Abbreviations: (fp) floor plate; (gVII/VIII) seventh/eighth cranial ganglion and associated nerve root; $(\mathrm{hn})$ Hensen's node; $(\mathrm{nc})$ neural crest; $(\mathrm{A}-\mathrm{C})$ proneuromeres; (rl-r8) rhombomeres $1-8$; (S1) first somite; (S2) second somite. 
suggests that rhombomere boundaries are barriers to cell migration. If this suggestion is true, it would lend weight to the second explanation, but the issue of how this boundary sharpening process takes place is far from resolved.

While the anterior boundary is being refined, the level of Ghox-lab protein greatly increases in rhombomere 4. Shortly afterward, a noticeable decline in signal intensity begins in rhombomere 5 , which ends with a complete shutoff of the gene by stage 12 (Figs. 2J and 4). By stage 17, expression has also been lost in rhombomere 6 (Figs. 1C and 4). It remains to be determined which cellautonomous regulatory genes and/or external signals carry out this sculpting process.

\section{Relationship of Ghox-lab to other vertebrate labial cognates}

In Drosophila, there is a single gene, labial, which can be identified as the prototype of the mouse genes Hox-1.6 (Baron et al. 1987; La Rosa and Gudas 1988) and Hox-2.9 (Murphy et al. 1989; sequence courtesy of Frohman et al. 1990), human Hox 2 I (Boncinelli et al. 1989), and Ghox-lab (Sundin et al. 1990). This relationship is inferred from similarities in their homeo box sequences and their chromosomal locations within homeo box gene clusters (Boncinelli et al. 1989). In principle, the chromosomal duplications that led to four vertebrate Hox clusters allow for up to four labial cognates (Duboule and Dollé 1989; Graham et al. 1989; for review, see Boncinelli et al. 1989|. Until all of these genes have been characterized fully, the question of homology cannot be resolved; however, a preliminary comparison of the expression patterns of Ghox-lab with that of Hox-1.6 and Hox-2.9 sheds some light on this issue.

In mouse embryos, after the formation of rhombomere 4, Hox-2.9 mRNA is found only in this rhombomere (Murphy et al. 1989; Wilkinson et al. $1989 \mathrm{~b})$, and this constitutes a striking similarity with the Ghox-lab pattern. Hox-1.6 lacks the distinctive island of expression in rhombomere 4 (Duboule and Dollé 1989) and therefore seems less likely to be the mouse homolog of Ghox-lab. In the case of Hox-2.9, it should be noted that there appear to be substantial differences in the pattern of expression within the early, prerhombomere neuroepithelium. Unlike the early chick, which shows uniform levels of expression within the posterior two-thirds of the embryo (see Fig. 5C in Sundin et al. 1990), in the equivalent mouse embryo (day 8) the highest levels of expression are at the caudal end of the embryo, with a considerable decline toward more anterior regions (see Fig. $3 \mathrm{H}$ in Wilkinson et al. 1989b). The observations made by Wilkinson and co-workers (1989b) led them to conclude that Hox-2.9 is not expressed at an appropriate location within the hindbrain at a time when Krox 20 reveals the definition of rhombomere boundaries and suggested that this argues against a role for Hox-2.9 in segment formation. It should be noted that in contrast to this, Frohman et al. (1990) have found Hox-2.9 mRNA in the presumptive hindbrain of the early neural plate stage embryo, and this suggests that its domain of expression may be equivalent to that of Ghox-lab. Therefore, the early prerhombomere phases of Hox-2.9 and Ghox-lab expression could be similar in their essential features and perform homologous functions.

In the chick, we have shown that for embryos ranging from 1 to 7 somites (Hamburger-Hamilton stages 7-9), the domain of Ghox-lab expression extends from the presumptive mid-hindbrain region to the posterior end of the embryo. The recent single cell lineage work of Fraser and collaborators (1990) indicates that the clonal restriction of cells to either side of the rhombomere $3 / 4$ border happens when this morphological boundary first appears, at about stage 9. Taken together, these observations in the chick raise the possibility that this early pattern of Ghox-lab expression prefigures at least an approximate location of the fourth rhombomere.

\section{Methods}

\section{In situ hybridization}

In situ hybridization was carried out with $7-\mu \mathrm{m}$ paraffin sections exactly as described in Sundin et al. (1990). Antisense riboprobe labeled with ${ }^{35} \mathrm{~S}$ was prepared from a 293-bp stretch of DNA within the $3^{\prime}$ half of the upstream exon (nucleotides 280-573, as defined in Sundin et al. 1990). This sequence is unique to Ghox-lab and does not cross-react with other homeo box genes, even at low stringency.

\section{Preparation of antibodies}

A fragment of the Ghox-lab genomic clone was generated by trimming with exonuclease III and cloning into a Bluescript $\mathrm{KS}+$ plasmid. The trimmed clone begins 12 nucleotides upstream of the amino terminus, spans the 204 amino acid-coding region of the upstream exon, and ends at an SstI (SacI) site located within the adjoining intron. A key feature of this fragment is that it does not encode the homeo box and has only small regions of homology to the mouse Hox-1.6 gene that was used to isolate the clone (Sundin et al. 1990). The fragment was excised with the Bluescript polylinker sites BamHI and HindIII and cloned into the TrpE expression vector PATH 1 (Dieckman and Tzagoloff 1985). The fusion protein was expressed at high levels in E. coli strain XL1-blue (Stratagene). The bacteria were grown in M9 medium with $0.5 \%$ casamino acids, with 50 $\mu \mathrm{g} / \mathrm{ml}$ 3-indolepropionic acid added as an inducer (Morse et al. 1969 , followed by growth for $6 \mathrm{hr}$ at $37^{\circ} \mathrm{C}$. Inclusion bodies containing the fusion protein were prepared by sonication of cells in TE [10 mM Tris (pH 7.4), $1 \mathrm{~mm}$ sodium EDTA] containing $0.2 \mathrm{mM}$ PMSF at $0^{\circ} \mathrm{C}$ until complete lysis, followed by two successive washes in TE containing $1 \%$ (vol/vol) Triton and $2 \mathrm{M}$ urea. The final pellet was resuspended in TE containing $6 \mathrm{M}$ urea, incubated at $25^{\circ} \mathrm{C}$ for $10 \mathrm{~min}$, and centrifuged at $45,000 \mathrm{rpm}$ for $30 \mathrm{~min}$ at $4^{\circ} \mathrm{C}$. Fusion protein in the supernatant extract was purified further by electrophoresis in SDS $/ 10 \%$ acrylamide gels. Bands were located by a conventional staining of the gels for $1 \mathrm{~min}$ in Coomassie Blue, followed by rinsing in water for $30 \mathrm{~min}$. Gels were frozen, ground into fine particles, mixed with Freund's adjuvant, and used to immunize three rabbits. Immunizations were performed by the Berkeley Antibody Company (Richmond, CA). The initial injection contained $\sim 500 \mu \mathrm{g}$ of protein, whereas the booster injections (with incomplete Freund's adjuvant) each contained half this amount. 


\section{Affinity purification of antibodies}

A second fusion protein, this time consisting of LacZ and the first 94 amino acids of the predicted Ghox-lab protein, was prepared by cloning a BamHI-PstI fragment of the trimmed Ghoxlab clone into the expression vector PUR 292 (Rüther and Müller-Hill 1983). The approach uses a two-fusion-protein method to select positively only antibodies specific for protein encoded by the cloned chick DNA (Gaul et al. 1987). Nitrocellulose-bound protein serves as the immobile affinity matrix in an affinity purification procedure similar to that of Olmstead (1981).

Preparation of affinity matrix The $6 \mathrm{M}$ urea inclusion body extract containing the LacZ fusion protein was prepared exactly as described for the TrpE protein. Electrophoresis of the LacZ fusion protein was carried out in $7.5 \%$ acrylamide gels, which were then transferred electrophoretically (Towbin et al. 1979) to nitrocellulose filters. The filters were stained with Ponceau S to visualize the fusion protein and air-dried, after which strips containing the immobilized fusion protein were excised and stored at $-20^{\circ} \mathrm{C}$.

Affinity purification About $40 \mathrm{~cm}^{2}$ of these strips were blocked in three changes of $5 \%$ milk TST [ $5 \%$ (wt/vol) Carnation nonfat dry milk, $10 \mathrm{~mm}$ Tris-Cl (pH 7.4), $150 \mathrm{~mm} \mathrm{NaCl}$, $0.1 \%$ Tween 20]. Four milliliters of anti-fusion protein rabbit serum was diluted with $16 \mathrm{ml}$ of $5 \%$ milk TST, and the strips were incubated with this mixture overnight at $4^{\circ} \mathrm{C}$, with gentle agitation. After five 5-min washes in $1 \%$ milk TST, a 1 -hr wash in $1 \%$ milk TST at $\sim 23^{\circ} \mathrm{C}$ and, finally, two 1 -min washes in $150 \mathrm{mM} \mathrm{NaCl}$, bound antibodies were eluted in $10 \mathrm{ml}$ of 150 $\mathrm{mm}$ glycine $(\mathrm{pH} 2.7)$ at $\sim 23^{\circ} \mathrm{C}$ for $10 \mathrm{~min}$, followed by immediate neutralization of the solution by the addition of $1 \mathrm{ml}$ of 2 $\mathbf{M}$ Tris ( $\mathrm{pH} 8.2$ ). Antibodies were stabilized by the addition of an equal volume of $10 \% \mathrm{TST}$, frozen quickly on dry ice, and stored in small aliquots at $-80^{\circ} \mathrm{C}$.

\section{Immunohistochemistry}

Fixation of embryos Embryos were incubated and staged according to Hamburger and Hamilton (1951), dissected, and collected in ice-cold PBS. They were then fixed in $4 \%$ paraformaldehyde-PBS for $15 \mathrm{~min}$ at $\sim 23^{\circ} \mathrm{C}$, rinsed briefly in ice-cold PBS, transferred to methanol at $\sim 23^{\circ} \mathrm{C}$ for $30 \mathrm{~min}$, and stored at $-20^{\circ} \mathrm{C}$.

Frozen sections Embryos in methanol were rehydrated stepwise into TS [10 $\mathrm{mM}$ Tris (pH 7.4), $150 \mathrm{mM} \mathrm{NaCl}]$ containing $0.5 \%$ sucrose. The embryos were warmed to $37^{\circ} \mathrm{C}$, incubated in TS containing $0.5 \mathrm{M}$ sucrose and $7.5 \%(\mathrm{wt} / \mathrm{vol})$ gelatin (Sigma 300 Bloom) for $1 \mathrm{hr}$ at $37^{\circ} \mathrm{C}$ and, finally, chilled on ice for $1 \mathrm{hr}$. Blocks were trimmed at $4^{\circ} \mathrm{C}$ and frozen by immersion in $n$-pentane (dry-ice chilled) for $90 \mathrm{sec}$. Sections $(10 \mu \mathrm{m})$ were cut at $-29^{\circ} \mathrm{C}$ and transferred to gelatinized slides, air-dried for $30 \mathrm{~min}$ at $\sim 23^{\circ} \mathrm{C}$, and stored at $-80^{\circ} \mathrm{C}$. Gelatin was removed by incubation in TS at $42^{\circ} \mathrm{C}$ for $10 \mathrm{~min}$, followed by blocking with centrifugation-clarified $5 \%$ milk TST for $1 \mathrm{hr}$. The first antibody was diluted into $5 \%$ milk TST, spin-clarified in a microfuge at $12,000 \mathrm{rpm}$ at $4^{\circ} \mathrm{C}$ for $20 \mathrm{~min}$, applied to the sections, and incubated for $30 \mathrm{~min}$ in a humidified chamber at $\sim 23^{\circ} \mathrm{C}$. Sections were then washed five times in $1 \%$ milk TST, 2 min per wash. Biotinylated second antibody (goat anti-rabbit IgG or horse anti-mouse IgM; Vector Laboratories) was diluted $1: 100$ in $5 \%$ milk TST. Incubations and washes were as for the first antibody. Avidin-HRP (avidin-horseradish peroxidase; Vector) was applied to the sections at $1: 100$ dilution and incubated exactly as for the second antibody. After two final 10-min washes with TST, a solution of TS containing $300 \mu \mathrm{g} / \mathrm{ml}$ diaminobenzidine and $0.03 \% \mathrm{H}_{2} \mathrm{O}_{2}$ was applied to the sections for 15 min at $\sim 23^{\circ} \mathrm{C}$, after which they were rinsed in water, air-dried, and mounted in methyl salicylate/Canada balsam as described previously (Sundin et al. 1990).

Embryo whole mounts Fixed embryos (stages 8-12) were rehydrated stepwise from methanol to TST, and blocked in clarified $5 \%$ milk TST at $4^{\circ} \mathrm{C}$ for $2 \mathrm{hr}$. The first antibody [either a rabbit anti-Ghox-lab or mouse monoclonal anti-leu 7 (Becton Dickinson)], was diluted in 5\% milk TST and spin-clarified. The blocked embryos were incubated in this solution for 10-16 $\mathrm{hr}$ at $4^{\circ} \mathrm{C}$, with gentle agitation on a rocker platform. The embryos were then washed in $1 \%$ milk TST, with five changes of solution over a period of $4 \mathrm{hr}$ at $\sim 23^{\circ} \mathrm{C}$. They were then incubated in biotinylated goat anti-rabbit (or horse anti-mouse) IgG, heavy- and light-chain-specific (Vector), diluted 1:200 in clarified $5 \%$ milk TST at $\sim 23^{\circ} \mathrm{C}$ for $4 \mathrm{hr}$, followed by $4 \mathrm{hr}$ of washes in $1 \%$ milk TST. The final incubation was in a $1: 500$ dilution of avidin-HRP in clarified $5 \%$ milk TST for $10-16 \mathrm{hr}$ at $\sim 23^{\circ} \mathrm{C}$, followed by $4 \mathrm{hr}$ of washes in $1 \%$ milk TST. The peroxidase reaction was carried out by incubation in TS containing $300 \mu \mathrm{g} / \mathrm{ml}$ diaminobenzidine for $10 \mathrm{~min}$, followed by addition of $\mathrm{H}_{2} \mathrm{O}_{2}$ to a final concentration of $0.03 \%$, and incubated for 15 $\min$ at $\sim 23^{\circ} \mathrm{C}$. Embryos were washed with TS, and dehydrated stepwise with ethanol. They were cleared and viewed in $2: 1$ benzyl benzoate and benzyl alcohol.

\section{Acknowledgments}

We thank Morris Birnbaum and Brian Burke for advice concerning antibody preparation, F.M. Boyce for his affinity purification protocol, Gail Martin for sharing unpublished data, Drew Noden for discussions concerning cranial neural crest, and Tom Vogt for contributing mouse embryos. G. Martin, F. Boyce, Kevin Pang, and T. Vogt read and provided valuable comments on the manuscript. O.S. thanks Howard Green and the Department of Cellular and Molecular Physiology for support. This work was funded chiefly by the American Cancer Society (NP 630/630A), with additional support from the Lucille P. Markey Charitable Trust.

The publication costs of this article were defrayed in part by payment of page charges. This article must therefore be hereby marked "advertisement" in accordance with 18 USC section 1734 solely to indicate this fact.

\section{References}

Akam, M. 1989. Homologous gene clusters in insects and vertebrates. Cell 57: 347-349.

Akam, M., I. Dawson, and G. Tear. 1988. Homeotic genes and the control of segment diversity. Development (suppl.) 104: 123-133.

Baron, A., M.S. Featherstone, R.E. Hill, A. Hall, B. Galliot, and D. Duboule. 1987. Hox 1.6: A mouse homeobox-containing gene member of the Hox-1 complex. EMBO I. 6: 2977-2986.

Boncinelli, E., D. Acampora, M. Pannese, M. D'Esposito, R. Somma, G. Gaudino, A. Stornaiuolo, M. Cafiero, and A. Simeone. 1989. Organization of human class I homeobox genes. Genome 31: 128-143.

Covell, D.A. and D.M. Noden. 1989. Embryonic development of the chick primary trigeminal sensory-motor complex. $I$. Comp. Neurol. 286: 488-503.

D'Amico-Martel, A., and D.M. Noden. 1983. Contributions of placodal and neural crest cells to avian peripheral ganglia. Am. J. Anat. 166: 445-468.

Dieckman, C. and A. Tzagoloff. 1985. Assembly of the mitochondrial membrane system. I. Biol. Chem. 260: 1513- 
1520.

Diederich, R.J., V.K. Merrill, M.A. Pultz, and T.C. Kaufman. 1989. Isolation, structure, and expression of labial, a homeotic gene of the Antennapedia Complex involved in Drosophila head development. Genes Dev. 3: 399-414.

Duboule, D. and P. Dollé. 1989. The structural and functional organization of the murine Hox gene family resembles that of Drosophila homeotic genes. EMBO J. 8: 1497-1505.

Duncan, I. 1987. The Bithorax complex. Annu. Rev. Genet. 21: 285-319.

Fraser, S., R. Keynes, and A. Lumsden. 1990. Segmentation in the chick embryo hindbrain is defined by cell lineage restrictions. Nature 344: 431-435.

Frohman, M.A., M. Boyle, and G. Martin. 1990. Isolation of the mouse Hox 2.9 gene; analysis of embryonic expression suggests that positional information along the anterior-posterior axis is specified by mesoderm. Development (in press).

Gaul, U., E. Seifert, R. Schuh, and H. Jaeckle. 1987. Analysis of krueppel protein distribution during early Drosophila development reveals posttranslational regulation Cell 50: 639647.

Gehring, W.J. 1987. Homeo boxes in the study of development. Science 236: 1245-1252.

Graham, A., N. Papalopulu, and R. Krumlauf. 1989. Murine and Drosophila homeobox gene complexes have common features of organization and expression. Cell 57: 367-378.

Hamburger, V. and H. Hamilton. 1951. A series of normal stages in the development of the chick embryo. J. Morphol. 88: 49-92.

Holland, P.W.H. and B.L.M. Hogan. 1988. Expression of homeo box genes during mouse development: A review. Genes Dev. 2: 773-782.

Jessell, T.M., P. Bovolenta, M. Placzek, M. Tessier-Lavigne, and J. Dodd. 1989. Polarity and patterning of the neural tube: The origin and function of the floor plate. Ciba Found. Symp. 144: 255-280.

Keynes, R. and A. Lumsden. 1990. Segmentation and the origin of regional diversity in the vertebrate central nervous system. Neuron 2: 1-9.

Kuratani, S., S. Tanaka, Y. Ishikawa, and C. Zukeran. 1988. Early development of the facial nerve in the chick embryo with special reference to the development of the chorda tympani. Am. J. Anat. 182: 169-182.

La Rosa, G.J. and L.J. Gudas. 1988. Early retinoic acid-induced F9 teratocarcinoma stem cell gene ERA-1: Alternate splicing creates transcripts for a homeobox-containing protein and one lacking a homeobox. Mol. Cell. Biol. 8: 3906-3917.

Lawrence, P.A. 1988. The present status of the parasegment. Development (suppl.) 104: 61-65.

Le Lièvre, C.S. and N.M. Le Douarin. 1982. The early development of cranial sensory ganglia and the potentialities of their component cells studied in quail-chick chimeras. Dev. Biol. 94: 291-310.

Lewis, E.B., 1978. A gene complex controlling segmentation in Drosophila. Nature 276: 565-570.

Lumsden, A. and R. Keynes. 1989. Segmental patterns of neuronal development in the chick hindbrain. Nature 337: 424-428.

Macdonald, P.M. and G. Struhl. 1986. A molecular gradient in early Drosophila embryos and its role in specifying the body pattern. Nature 324: 537-545.

Mahaffey, J.W. and T.C. Kaufmann. 1989. The homeotic genes of the Antennapedia complex and the Bithorax complex of Drosophila. A primer in developmental biology (ed. G.M. Malacinski), pp. 329-360. Macmillan, New York.

Martinez-Arias, A. and P.A. Lawrence. 1985. Parasegments and compartments in the Drosophila embryo. Nature 313: 639642.

McGinnis, W., R.L. Garber, J. Wirz, A, Kuroiwa, and W. Gehring. 1984. A homologous protein coding sequence in Drosophila homeotic genes and its conservation in other metazoans. Cell 37: 403-408.

Morse, D.E., D. Mosteller, C. Yanofsky. 1969. Dynamics of synthesis, translation, and degradation of trp operon messenger RNA in Escherichia coli. Cold Spring Harbor Symp. Quant. Biol. 34: 725-740.

Murphy, P., D.R. Davidson, and R.E. Hill. 1989. Segment-specific expression of a homeobox-containing gene in the mouse hindbrain. Nature 341: 156-159.

Noden, D.M. 1983. The role of the neural crest in patterning of avian cranial skeletal, connective and muscle tissues. Dev. Biol. 96: 144-165.

Olmstead, J.B. 1981. Affinity purification of antibodies from diazotized paper blots of heterogeneous protein samples. I. Biol. Chem. 256: 11955-11957.

Orr, H. 1887. Contribution to the embryology of the lizard. $J$. Morphol. 1: 311-372.

Peifer, M., F. Karch, and W. Bender. 1987. The bithorax complex: Control of segmental identity. Genes Dev. 1: 891-898.

Qian, Y.Q., M. Billeter, G. Otting, M. Müller, W.J. Gehring, and K. Wüthrich. 1989. The structure of the Antennapedia homeodomain determined by NMR spectroscopy in solution: Comparison with prokaryotic repressors. Cell 59: 573-580.

Rüther, U. and B. Müller-Hill. 1983. Easy identification of cDNA clones. $E M B O$ I. 2: 1791-1794.

Schoenwolf, G.C., H. Bortier, and L. Vakaet. 1989. Fate mapping the avian neural plate with quail/chick chimeras: Origin of prospective median wedge cells. J. Exp. Zool. 249: $271-278$.

Spratt, N.T. 1952. Localization of the prospective neural plate in the early chick blastoderm. J. Exp. Zool. 20: 109-130.

Struhl, G., K. Struhl, and P.M. McDonald. 1989. The gradient morphogen bicoid is a concentration-dependent transcriptional activator. Cell 57: 1259-1273.

Sundin, O.H., H.G. Busse, M.B. Rogers, L.J. Gudas, and G. Eichele. 1990. Region specific expression in early chick and mouse embryos of Ghox-lab and Hox 1.6, vertebrate homeobox containing genes related to Drosophila labial. Development 108: 47-58.

Towbin, H., T. Staehelin, and J. Gordon. 1979. Electrophoretic transfer of proteins from polyacrylamide gels to nitrocellulose sheets: Procedure and some applications. Proc. Natl. Acad. Sci. 76: 4350-4354.

Vaage, S. 1969. The segmentation of the primitive neural tube in chick embryos (Gallus domesticus). Adv. Anat. Embryol. Cell Biol. 41: 1-88.

Vincent, M. and J.P. Thiery. 1984. A cell surface marker for neural crest and placodal cells. Dev. Biol. 103: 468-481.

von Baer, K.E. 1828. Ueber die Entwicklungsgeschichte der Thiere, Bd. 1-3. Koenigsberg.

Wilkinson, D.G., S. Bhatt, P. Chavrier, R. Bravo, and P. Charnay. 1989a. Segment-specific expression of a zinc-finger gene in the developing nervous system of the mouse. Nature 337: 461-464.

Wilkinson, D.G., S. Bhatt, M. Cook, E. Boncinelli, and R. Krumlauf. 1989b. Segmental expression of Hox-2 homeobox-containing genes in the developing mouse hindbrain. Nature 341: 405-409.

Winslow, G.M., S. Hayashi, M. Krasnow, D.S. Hogness, and M.P. Scott. 1989. Transcriptional activition by the Antennapedia and fushi tarazu proteins in cultured Drosophila cells. Cell 57: 1017-1030. 


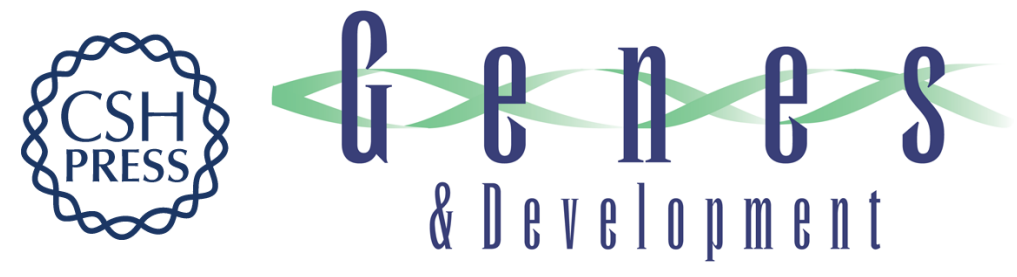

\section{A homeo domain protein reveals the metameric nature of the developing chick hindbrain.}

O H Sundin and G Eichele

Genes Dev. 1990, 4:

Access the most recent version at doi:10.1101/gad.4.8.1267

References This article cites 45 articles, 12 of which can be accessed free at: http://genesdev.cshlp.org/content/4/8/1267.full.htmI\#ref-list-1

License

Email Alerting Receive free email alerts when new articles cite this article - sign up in the box at the top Service right corner of the article or click here.

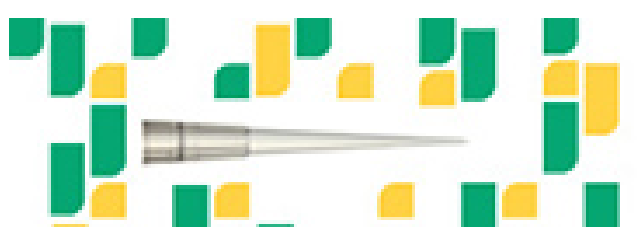

Focused on your science. 